\title{
Description of Immature Stages and Male of Cosmolaelaps keni (Laelapidae)
}

\author{
A. K. Nasr"; S. A. El-Sawi "; S. M. O. El-Bishlawy "* and M. L. Abd-Elwahab \\ ${ }^{*}$ Pests and Plant Protection Dept.. National Rescarch (entre, Dokki. Cairo, Egypt. \\ ** Zoology and Agric. Nematology Dept.. Fac, of Agric.. Cairo Ĺniv., Cairo, Lgypt.
}

\begin{abstract}
Immature stages and male of the laelapid mite,Cosmolaelaps keni I lafez. Fl-Badry and Nasr, are described and illustrated.
\end{abstract}

Key words: Acari; Cosmolaelaps; Mesostigmata.

\section{INTRODUCTION}

The genus of Cosmolaelaps (Berlese, 1903), is cosmopolitan and most of its species are free-livings in soil, litter, organic matter, humus of trees, moss, or on rodents or in its nests (Evans \& Till, 1966 \&1979; Bregetova, 1977 and Ramdoori, et al., 2014). In spite of this genus contains about 115 species representing most the country of the world (Moreira et al., 2014), the description of their immature stages are very poor, as only four species have been described (Afifi and Van Der Geest, 1984; El-Borolossy, 1993; Fouly et al., 1997 and Fouly \&Al-Rehiayani, 2014).

In Egypt, this genus is represented by four species (C. zachvatkinae Sherif \& Afifi 1980, C. keni Hafez, Elbadry \& Nasr 1982, C. longus Hafez, Elbadry \& Nasr 1982 and C. paravacus Nasr \& Nawar 1989). Theredore, the aim of the present study is to describe and illustrate the male and immature stages of C. keni.

\section{MATERIALS AND METHODS}

During the biological studies of Cosmolaelaps keni, ten individuals from each stage (egg, larva, protonymph, deutonymph) and male were after cleared in Nesbitt's fluid, and mounted in Hoyer's media on microscope slides. The line drawings and examinations of the specimens were preformed with an Olympus phase contrast microscope equipped with a drawing tube. The nomenclature used for idiosomal chaetotaxy is that of Lindquist \& Evans (1965), leg chaetotaxy is that of Evans (1963). All measurements are given in micrometers $(\mu \mathrm{m})$ as means (minimum maximum). The specimens were deposited in the collection of Acari, in the Department of Pests \& Plant Protection, National Research Centre.

\section{RESULTS AND DISCUSSION}

Cosmolaelaps keni (Hafez, El-Badry and Nasr). Hypoas pis (Cosmolaelaps) keni Hafez, El-Badry and Nasr.

Cosmolaelaps keni (Hafez, El-Badry and Nasr) Zaher 1986; Moreira et al. 2014 and Ramroodi et al., 2014.
Egg: Oval, about $266 \mu$ long and $190 \mu$ wide $(\mathrm{n}=7)$, milky colour with first deposited.

Larva:

Dorsum (Fig.1B): Idiosoma 297 $\mu$ long and $202 \mu$ wide $(n=5)$ at level of leg III.Body elliptical, whitis $h$ when alive, with 3 pairs of legs. Hypostome with 2 pairs of simple setae (hp1\& hp2), corniculi weakly sclerotized and convergent and closed; deutosternum with fantily dentated 6 transverse rows. Chelicera chelate and weakly sclerotized; dorsum with 14 pairs of simple setae: 10 pairs on podonotal region $\left(\mathrm{j}_{1}, \mathrm{j}_{3}-\mathrm{j}_{6}\right.$, $\mathrm{z}_{2}, \mathrm{z}_{4}, \mathrm{z}_{5}, \mathrm{~s}_{4}$ and $\mathrm{s}_{6}$ ), opisthonotal region with 4 pairs of setae $\left(J_{5}, Z_{4}, S_{4}\right.$ and $\left.S_{5}\right)$. Length of some dorsal setae: $j_{1}=(15-18), j_{6}=(31-34), z_{4}=(11-15), Z 4=(24-$ 29).

Venter: (Fig.1A): Tritosternum with a slender base and developed pairs of setoses laciniae; sternal shield littly distinct, with 3 pairs of sternal setae; opisthogaster with 4 pairs of setae $\left(\mathrm{JV}_{1}, \mathrm{JV}_{2}, \mathrm{Jv}_{5}\right.$ and $\mathrm{Zv}_{2}$ ) in addition to the 3 anal setae; anal shield weakly sclerotized, post-anal and paranal setae simple. Length of some ventral setae: $\mathrm{st}_{1}=(14-17), \mathrm{Jvl}=(12-$ $15)$, postanals $=(31-37)$, paranals $=(22-28)$.

\section{Chae totactic formula of ge nua and tibiae of legs as} follows:

\begin{tabular}{lccc}
\hline & I & II & III \\
\hline Genu & $1 \frac{2}{1} \frac{2}{1} 1$ & $1 \frac{2}{0} \frac{2}{0} 1$ & $1 \frac{2}{0} \frac{2}{0} 1$ \\
\hline Tibia & $1 \frac{2}{1} \frac{2}{1} 1$ & $1 \frac{1}{1} \frac{2}{1} 1$ & $1 \frac{2}{1} 1$ \\
\hline
\end{tabular}

\section{Protonymph:}

Dorsum (Fig. 2A): Idiosoma $370 \mu$ long and $210 \mu$ wide $(n=5)$ at level of legs III. Body elliptical, whitish when alive with 4 pairs of legs. Hypostome, with 3 pairs of hypostomal (hypl, 2,3 ) setae and a pair of capitular, corniculi paralle1 and pointed; chelicera more sclerotized and fixed chela with 2 teeth; while the movable with 4 to 5 teeth,variable in size. Dorsal shield with 32 pairs of scimitar - like setae: which are 16 pairs on podonotal region $\left(\mathrm{j}_{1}-\mathrm{j}_{6}, \mathrm{z}_{2}-\mathrm{z}_{5}, \mathrm{~s}_{4}-\mathrm{s}_{6}, \mathrm{r}_{2}, \mathrm{r}_{3}, \mathrm{r}_{5}\right.$ and $\left.\mathrm{r}_{6}\right)$; while opisthonotal region bearing 16 pairs of setae 


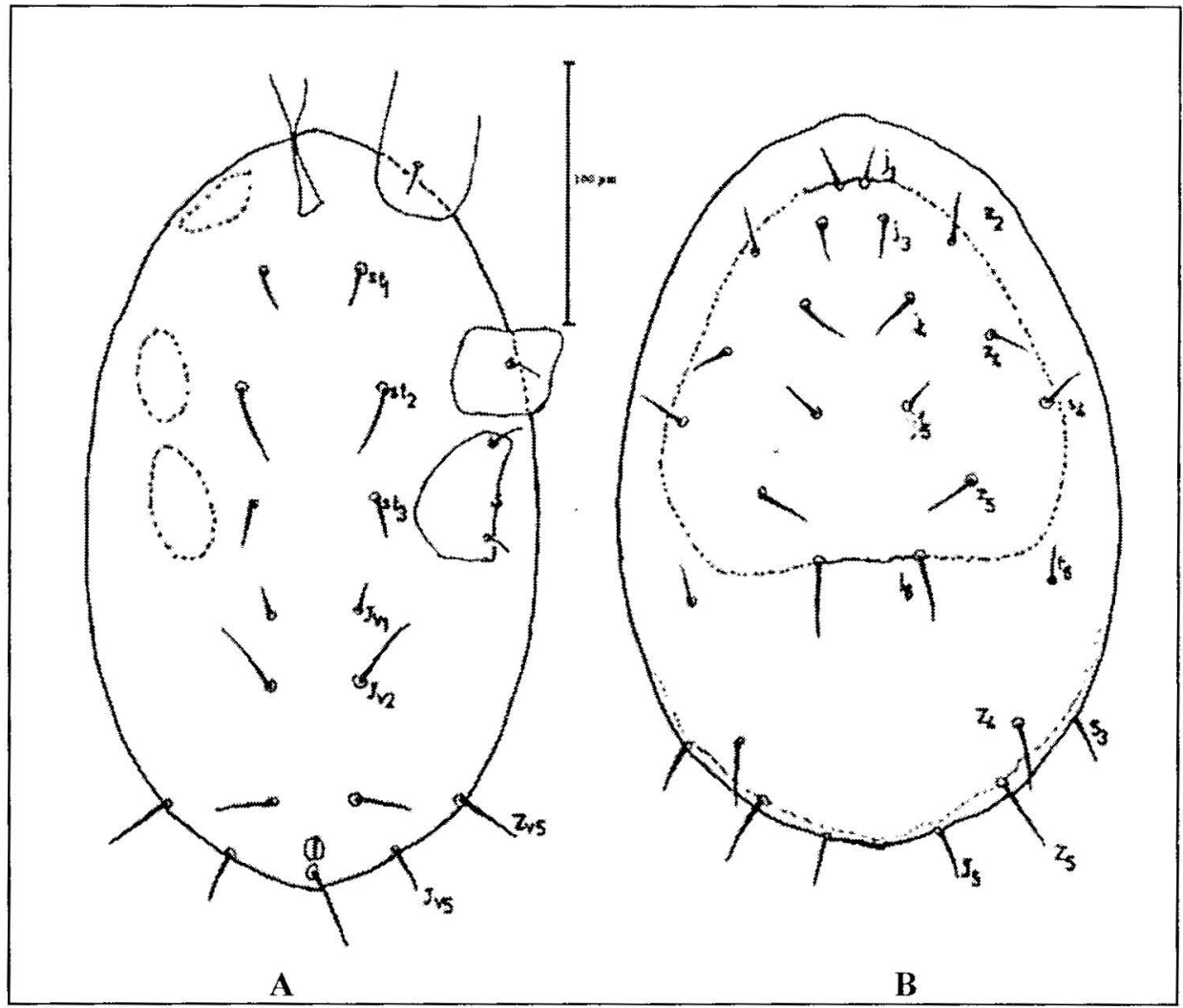

Fig. (1): Cosmolaelaps keni (Larvae): A. Venter idiosoma; B. Dorsum idiosoma.
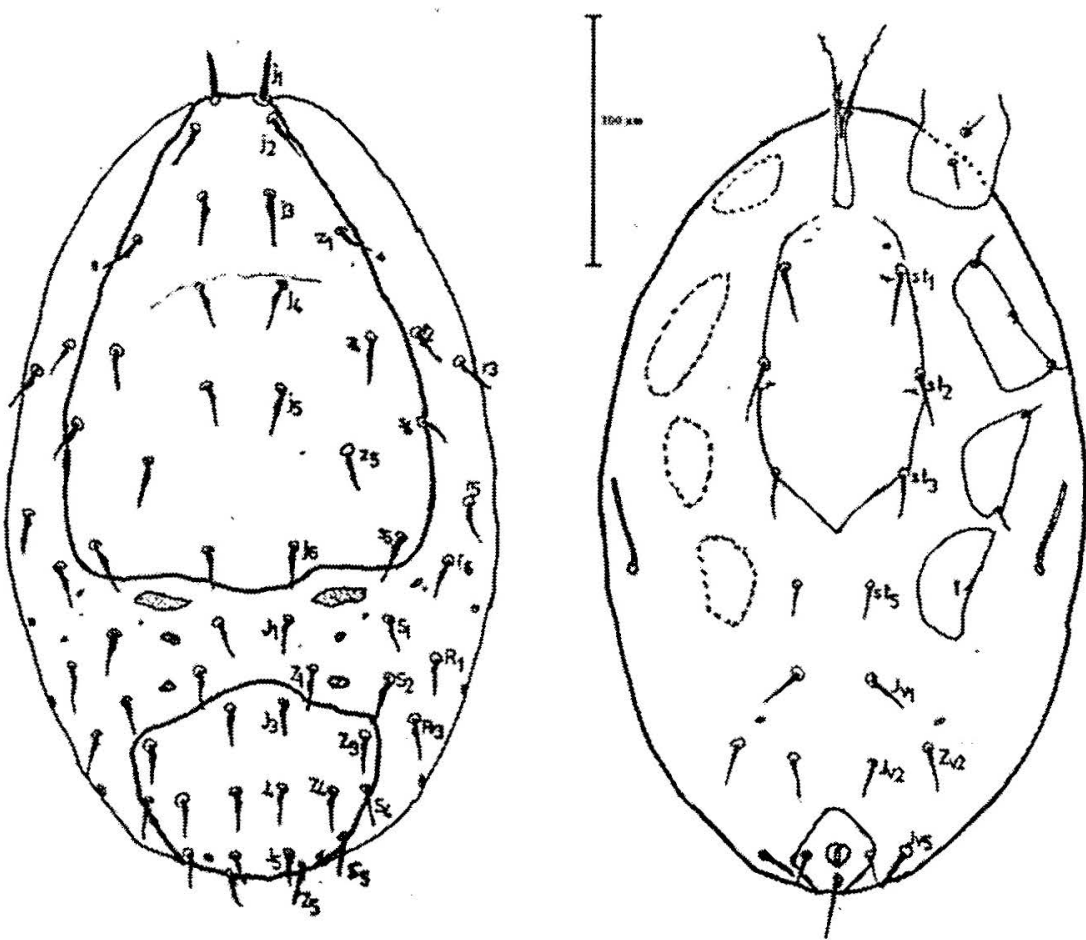

A $\quad$ B

Fig. (2): Cosmolaelaps keni (Protonymph): A. Dorsum idiosoma; B. Venter idiosoma. 


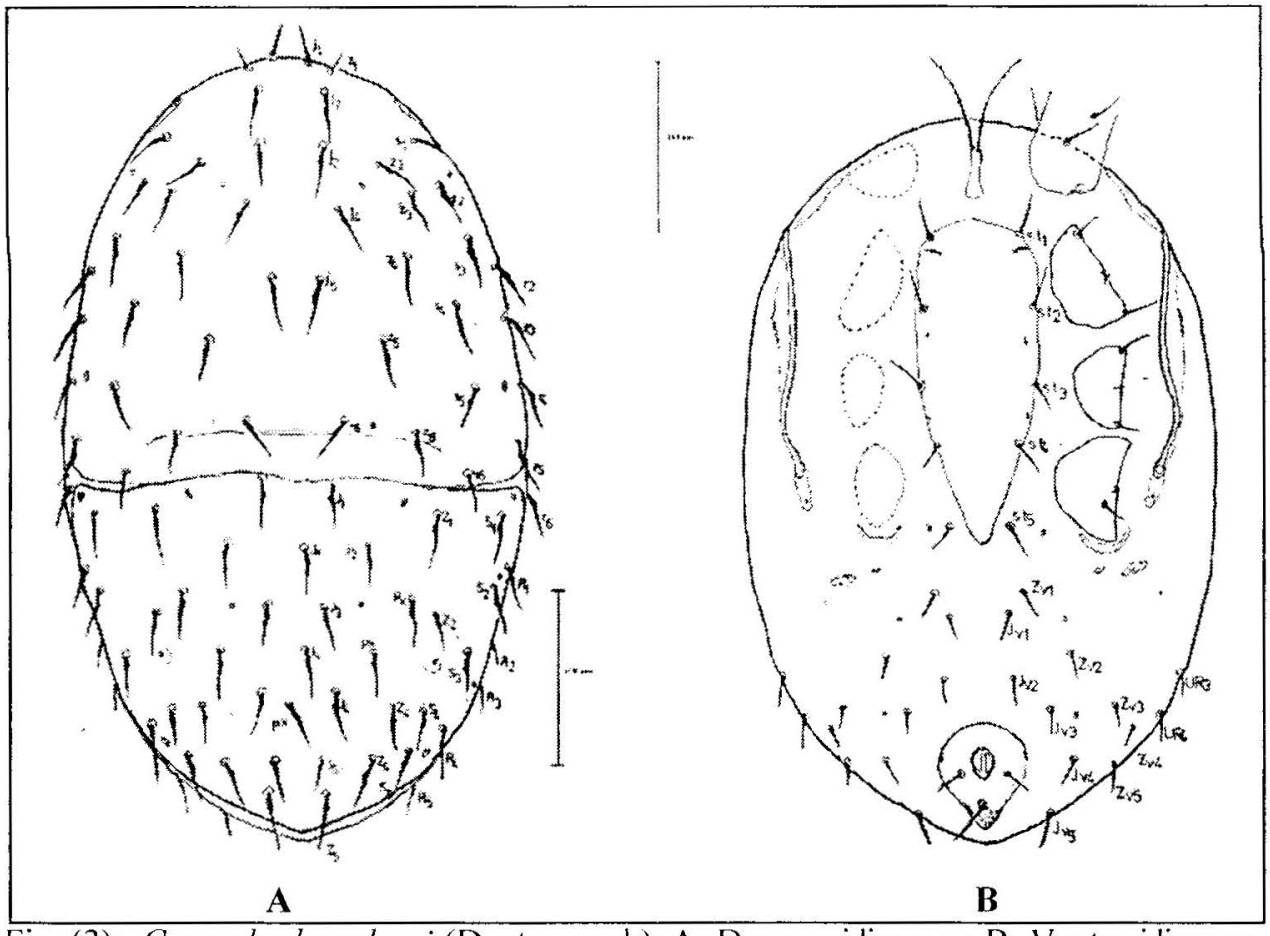

Fig. (3): Cosmolaelaps keni (Deutonymph): A. Dorsum idiosoma; B. Venter idiosoma.

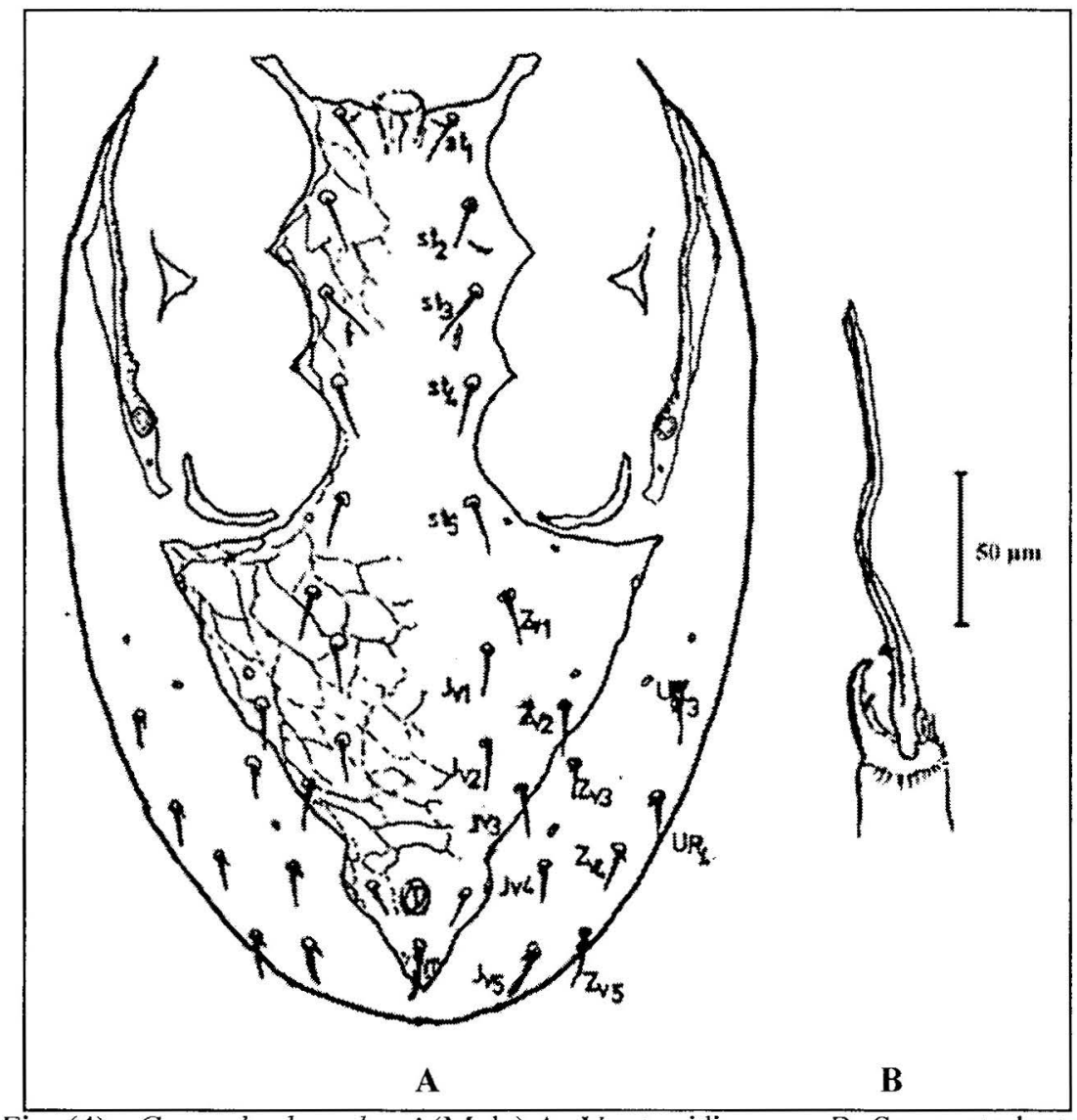

Fig. (4): Cosmolaelaps keni (Male):A. Venter idiosoma; B. Spermatodactyl. 
$\left(J_{1}-J_{5}, Z_{1}-Z_{5}, S_{2}-S_{5}-R_{3}\right.$ and $\left.R_{4}\right)$. Length of some dorsal setae: $j_{1}=(19-23), j_{6}=(16-20), z 4=(14-19)$, $Z_{4}=(21-25)$.

Ventrum (Fig.2B): Sternal shield weakly scelerotized with 3 pairs of setae and 2 pairs of lyrifissures. Genital setae free on integument. Opisthogaster with 4 pairs of setae $\left(\mathrm{Jv}_{1}, \mathrm{Jv}_{2}, \mathrm{Jv}_{5}\right.$ and $\mathrm{Zv}_{2}$ ). Anal shield subtriangular, with a pair of paraanal setae. Peritremes short, not passthrough coxae III. Length of some ventral setae: st $1=(20-25)$, pan $=(13-17)$, pon $=(25-30)$, gen.s. $=$ (20-23).

Chae totactic formula of ge nua and tibia of legs as follows:

\begin{tabular}{ccccc}
\hline & I & II & III & IV \\
\hline Genu & $1 \frac{2}{1} \frac{2}{1} 1$ & $1 \frac{22}{0} 1$ & $1 \frac{2}{0} \frac{2}{0} 0$ & $1 \frac{2}{0} \frac{2}{0} 0$ \\
\hline Tibia & $1 \frac{2}{1} \frac{2}{1} 1$ & $1 \frac{1}{1} \frac{2}{1} 1$ & $1 \frac{12}{1} 1$ & $1 \frac{1}{1} \frac{2}{1} 1$ \\
\hline
\end{tabular}

\section{De utonymph:}

Dors um (Fig. 3A): Idiosoma $455 \mu$ long and $325 \mu$ at its greatest wide. Body ovate, light-brown when alive. Dorsal shield entire, with lateral insicions and transverse line between setae $j_{6}-z_{6}$; it bears 40 pairs of setae; all setae scimitar - like except setae $j_{1}$ and $z_{1}$, which the former stout - like and the latherer simple; 23 pairs setae on podonotum which are $\left(j-j_{6}\right.$, $z_{1}-z_{6}, s_{1}-s_{6}$ and $r_{2}-r_{5}, r_{6}$ off shield) and 4 pairs of pore-like; 17 pairs on opisthonotum $\left(J_{1}-J_{5}, Z_{1}-Z_{5}\right.$, $\mathrm{S}_{1}-\mathrm{S}_{5}, \mathrm{px}_{1}$ and $\mathrm{px}_{2}$ ) and 3 unpaired setae between $\mathrm{J}$ series $\left(\mathrm{JX}_{2}-\mathrm{JX}_{4}\right)$ and 7 pairs of pore-like. Integument with 5 pairs of short and simple setae latero-ventrally $\left(U R_{2}\right.$ and $\left.U R_{3}\right)$.

Ventrum (Fig. 3B): Tritosternum well defined and normal. Sterno-genital shield, smooth, with pairs of simple setae and 3 pairs of lyrifissures; genital region narrowed and bears a pair of simple setae, free on integument. Opisthogaster with 10 pairs of simple setae $\left(J_{v_{1}}-J_{v_{5}}\right.$ and $\left.Z_{v_{1}}-Z v_{5}\right)$; anal shield subtriangular, and smooth, cribrum well developed, extending to level of post-anal setae, being thicker and longer than paranals. Two pairs of metapodal platelets, the internal, one minute. Peritreme, long, extends dorsally to level of setae $s_{1}$.

Chae totactic formula of genua and tibia of I - IV as follows:

\begin{tabular}{|c|c|c|c|c|}
\hline & I & II & III & IV \\
\hline Genu & $2 \frac{3}{2} \frac{3}{1} 2$ & $2 \frac{3}{1} \frac{2}{1}-2$ & $2 \frac{2}{1} \frac{2}{1} 1$ & $2 \frac{2}{1} \frac{3}{0} 1$ \\
\hline Tibia & $2 \frac{3}{2} \frac{3}{1} 2$ & $2 \frac{2}{1} \frac{2}{1} 2$ & $2 \frac{1}{1} \frac{2}{1} 1$ & $2 \frac{1}{1} \frac{3}{1} 2$ \\
\hline
\end{tabular}

Male:

Dorsal idiosoma: Dorsal shield 427 Long and 307 wide at its broadest point $(n=5)$ ornamentation and chaetotaxy as in female.

Ventral idiosoma (Fig. 4A). Sternal shield epigenal, endopodal, ventral and anal shields fused into a holoventral shield, reticulated with polygonal ornamentation, bearing 10 pairs of simple setae (st $t_{1-}$ $s t_{5}, J v_{1}-J v_{3}, Z v_{1}$ and $\left.Z v_{2}\right)$, and 7 pairs of pore-like structure, in addition to circumanal setae $\left(\mathrm{Jv}_{4}, \mathrm{Jv}_{5}, \mathrm{Zv}_{3}\right.$ $-Z_{v_{5}}, U R_{2}$ and $U R_{3}$ ) and 3 pairs of pore-like stricter.

Gnathosoma: As in female, except the shape of chelicera (Fig.4B) fixed chelae without teeth (edentate) with sharpepilusdenticle, movable chelae modified completely as spermatodactyle $(132-166)$ long and having two teeth.

\section{REFERENCES}

Afifi, A.M. and van Der Geest, L. P. S. 1984. Notes on the development and biology of the predaceous soil mite Cosmolaelaps claviger (Berlese, 1883) (Gamasida: Laelapidae). In: Griffiths, D. A. \& Bowanan, C. E. (Eds.), Acarol. II.Ellis HorwoodLimitedPublishers, pp.585-590.

Bregetova, N. G. 1977. Family Laelapidae Berlese, 1892. In: Ghilyarov, M. S. \& Bregetova, N. G. (Eds.), Key to the soil Inhabiting Mite. Mesostigmata. Nauka, Leningrad, pp. 483-554.

El-Borolossy, M. A. 1993. Biology and description of immature stages and male of Cosmolaelaps longus (Acari: Laelapidae). Egypt J. Appl. Sci., 8(12):444-453.

Evans, G. O. 1963. Observations on the chaetotaxy of legs in the free-living Gamasina (Acari: Mesostigmata). Bull. Brit. Mus. (Nat. Hist) Zool., 10: 275-303.

Evans, G. O. and Till, W. M. 1966. Studies on the British Dermanyssidae (Acari: Mesostigmata). Part II. Classification. Bull. Brit. Mus. (Nat. Hist.) Zool., 14: 107:370.

Evans, G. O. and Till, W. M. 1979. Mesostigmatid mites of Britian and Ireland (Chelicereta: Acari: Parasitiformes). Trans. Zool. Soc. London, 35(2): 139-270.

Fouly, A. H. and Al-Rehiayani, S. M. 2014. A new laelapid mite Cosmolaelaps qassimensis sp.nov(Gamasida: Laelapidae) from AgroEcosystem in Saudi Aribia. J. Entomol., 11(5): 261-272.

Fouly, A. H.; Childers, C. C. and Abou-Setta, M. M. 1997. Redescription of Cosmolaelaps simplex Berlese (Acari: Laelapidae) with notes on its male. Int. J. Acarol., 23: 33-37.

Hafez, S. M.; El-Badry, E. A. and Nasr, A. K. 1982. 
Soil mites of the family Laelapidae from Egypt (Acari: Mesostigmata). Res. Bull. Fac. Agri. Ain Shams Univ., 1-15.

Lindquist, E. E. and Evans, G. O. 1965. Taxonomic concepts in the Ascidae, with a modified setal nomenclature for the idiosomal of the Gamasina (Acarina: Mesostigmata) Mem. Ent. Soc. Can. 47: 1-64.

Moreira, G. F.; Klompen, H. and Moraes, G. J. 2014. Redefinition of Cosmolaelaps Berlese (Acari: Laelapidae) and description of five new species from Brazil. Zootaxa, 3784: 317-346. \asr. A. K. and Nawar. M. S. 1989. Two new species of laelapid mites from Egypt (Acri: Mesostigmata). Bull. Soc.Entomol., 68: 75-84.

Ramroodi. Sara; Hajizadeh, J. and Joharchi, O. 2014. Tw o new species of Cosmolaelaps Berlese (Acari: Laelapidae) from Iran. Zootaxa, 3847(4): 533544.

Sherif, G. M. and Afifi, A. M. 1980. Five new species of Mesostigmata mites inhabiting organic manures (Acari: Laelapidae). Proceedings of the $\mathrm{l}^{\mathrm{s}}$. Conference on Plant Protection Research Institute, Vol. 3, Cairo, Egypt, pp: 121-134. 